\title{
THE IMPACT OF DIGITAL STORYTELLING ON ACADEMIC ACHIEVEMENT OF SIXTH GRADE STUDENTS IN ENGLISH LANGUAGE AND THEIR MOTIVATION TOWARDS IT IN JORDAN
}

\author{
Dr. Yousef Ahmad ALJARAIDEH \\ ORCID: 0000-0003-3708-2962 \\ Faculty of Educational Sciences \\ Jerash University \\ Jerash, JORDAN
}

Received: 22/01/2019 Accepted: 22/07/2019

\begin{abstract}
This study aims to identify the impact of digital storytelling (DST) on academic achievement of sixth grade students in English language and their motivation towards it in Jordan.DST plays an important role in the maintenance and progress of English language. The research uses a quasi- experimental method. The sample of the study consists of (50) male students were purposefully chosen from public schools at Jerash governorate. They were distributed into two groups: Experimental group which has (25) students learning English language through DST, and control group which has (25) students. They are taught the same content in traditional way. The findings of the study showed that there are statistically significant differences in students' academic achievement and students' motivation towards learning English language due to teaching method in favor of experimental group which DST strategy is the main method used in English language. Statistically significant differences were also found in students' motivation towards learning English language due to teaching method in favor of experimental group. In the light of the results, some recommendations were set like integrating DST in the teaching and learning English language.
\end{abstract}

Keywords: Digital storytelling, academic achievement, English language, motivation, Jordan

\section{INTRODUCTION}

Recently, in the 21 st century teachers supposed to have information and communication skills (ICT). All modern strategies related to teaching and learning process are fully lies on technological skills. Thus, teachers should be able to promote their content using contemporary devices like; computer, internet, mobile learning, flipped learning and so on. To keep teachers up to date with those concepts, training courses should be actively implemented and more attention should be paid to teachers' professional development especially practical issues that deals with integration technology inside and outside the classroom sitting. Therefore, Digital storytelling (DST) should be one of the most potent in classroom teaching and learning process.

In the history of development teaching and learning method, DST has been thought of as a key factor in students' progress. DST is defined as a new story which is created by combining elements of multimedia such as text, sound, animation, video, and image (Dupain \& Maguire, 2005). Those elements are incorporated together by using certain computer software. The intentional goal of DST is explaining an ambiguous concept. Usually the duration of the given story is between two and ten minutes (Robin, 2016). Besides, DST presents the content in visual way, this kind of learning help the students keeping the abstract concepts as mental picture in their memory. In this perspective, Sarica and Usluel (2016) have indicated that students' writing skills and visual memory were significantly improved due to utilizing DST. In addition, it improves English language skills of students as well as their grammar and accent.

DST has seven basic elements: the first is point of view: It is the main theme that the author tries to send it to audiences. The second is dramatic question: It is a question like plot of story which grasps student's attentions in order to complete the story. In addition to that, this question will be answered at the end of story. The third emotional content: It is the ability to make connection between the theme of story and 
audiences' real life situations. The fourth is the gift of your voice: The way in which the story is designed to be understandable by student. The fifth is the power of the sound track: Sound, song, and music which are added to the timeline of story. The sixth is the economy: Delivering the content without elaboration. The final element is the pacing: The rhythm of the story, it might be fast or slow (Robin, 2008).

A primary concern of DST is the role it is playing in improving English language skills. Thus, designing and selecting DST gives the students a great chance for practicing English language in meaningful way (Wilson, 1997; Nilson, 2010). Besides, it could provide new generations with abilities and competences of 21 century such as self-efficacy, self- learning and self-progress. In addition, it can bring motivates that can help them to gain more achievements in education (Gay, 2010).Several studies investigating on DST Sylvester and Greenidge (2010); Malita and Martin (2010) have been carried out and revealed that integrating DST as instructional tool contribute in developing thinking skills, clarifying the ambiguity of the content, increasing communication skills and enhancing pedagogical and social levels of students. Similarly, Abdel-Hack and Helwa (2014); Meadows (2006) and Benmayor (2008) reported that DST reinforces students' engagement, increases reflection and improving retention.

\section{LITERATURE REVIEW}

Almost every paper that has been written on DST includes a section relating to the effectiveness of DST and the development of teaching methods. Atkas and Yurt (2017) evaluate the impact of DST on academic achievement of students in Turkish literature course. The sample of study has (61) students divided into two groups: Experimental with (31) students and control group with (30) students. The results showed that there is a significant difference in students' achievement between two groups in favor of experimental group which taught by using digital storytelling. Similarly, Kotluk and Kocakaya (2017) added that the experimental students' scores who taught physics through digital storytelling where greater than students' scores in control group. Also students' attitudes and self-efficacy were positively affected by DST.

A broader perspective has been adopted by Mokhtar, Halim and Kamarulzaman (2011) who argues that reading skills of English language has improved by using DST strategy. Thelinguistic wealth and number of vocabulary are increased. This view is supported by Yang Wu (2012) who writes DST has significantly a great impact on academic achievement and critical thinking of students in English as foreign language. Foelske (2014) explains that motivation; literacy skills and involvement are improved by using DST. Likewise, Dreyer (2017) holds the view that the professional growth program for teachers should include training courses on the use of DST. It can be concluded that DST has educational value at the school and university levels as well as developed skills of both students and teachers that finally can pour into main contributions of improvementand development of educationand learning process.

In fact, English as foreign language (EFL) courses should be taught by implementing DST for their positive impact on learning English language skills. In addition, DST can enhance the students' ability and motivation to improve their learning English (Tahriri, Tous \& Movahedfar, 2015). LoBello (2015) also supported this view via his research conducted to assess the impact of DST on the writing skills among fourth grade students in USA schools. The results of his study revealed that students' performance in writing skills were improved. Besides, students' motivation toward technical writing was significantly boosted positively. Correspondingly, Somdee \& Suppasetseree (2012) DST could help in enhancing students' writing skills and improving critical thinking among students. On the other hand, DTS also has a potential approach to enhance students' speaking skills. Abdel-Hack \& Helwa (2014) indicated that DST can do more than other approaches in developing the conversational ability of students.

On the teaching side, teachers usually use DST for educational purposes to improve their students' skills by providing them vital and practical experiences such as DST. The instructional aspect of DST and its impact on students' performance was discussed by Smeda, Dakich \& Sharda (2014). They pointed that DST is a meaningful tool to blend the content of subject matter taught with given tasks in order to create interactive environment inside the classroom. They also stated that DST as learning strategy has the ability to enhance student's performance through their active engagement in the given tasks. Robin (2016) stressed that involving students in the design of DST contributes in improving creativity and communication skills throughout they will be able to organize their information and ideas and recreating them into story form. 
The implications of DST have been addressed in several small-scale investigations as Chao \& Hung (2014) noted that students' oral proficiency, attitudes, perceptions, self-confidence, and motivation were improved by using DST. Also Connie (2017) indicated that both of students and teachers are expressed a high motivation towards DST. However, Gakhar (2007) conducted a study to assess pre-services teachers' attitudes and intention to use DST; he employed qualitative and quantitative procedures in order to collect a precise data. The finding showed that there are no significant differences in pre-services teachers' attitudes toward DST due to teaching method since their attitudes were high before integrating DST. In this case, motivated learners are somewhat prefer to working at all assignment still the end, with regards to some conditions they may face such as interruption or frustration (Ormrod, 2014).

Continuously, motivation was considered as a perquisite to ensure students' success. Data from several sources identified the increased of learning associated with motivation. Consistently numerous studies were attempted to explain that motivation is critical to many issues, such as the academic operational process, and the students' views and expectations should be progressed positively (Shernoff, Csikszentmiahlyi, Schneider $\&$ Shernoff, 2003). As well as Bredvick (2016) indicated that students were motivated and evolved actively with each other with significant collaboration while using technology. Kasami (2017) investigated that DST assignments have a direct impact on students' motivations for learning (EFL). Finally, recorded results were gathered by educational experts: Ivala, Gachago, Condy \& Chigona (2013) reported the production of digital stories improved the students' commitment in their learning, in which eventually led to a deep understanding of the subject matter.

\section{Problem Statement}

English language is the universal language; it is a crucial factor to ensure educational success in public and higher education. The past decade has seen the rapid development of using technology in learning process. Thus, most of educational institutions especially in the Third World countries try to provide students with English and technological skills to be able to cope with contemporary digital age. In the history of development English, DST has been thought of as a key factor in progressing the educational process especially in Jordan. In fact, there are set of factors affecting learning English language resembling; students' negative attitudes toward learning English language, lack of ICT devices in public schools, lack of ICT integration in teaching English language, and lastly the teaching strategies are heavily depended on conventional learning (Khan \& Khan, 2016; Alhmadi, 2014). So that, the current study tries to find whether a new strategy (DST) could improve students' achievement and motivation towards learning English language or not. This study tries to answer the following research questions:

1. Are there significant differences in students' academic achievement based on the teaching method (traditional way / DST)?

2. Are there significant differences in students' motivation toward learning English language regarding teaching method (traditional way/ DST)?

\section{Research Objectives}

The study offers some important insights into the following objectives:

1. Identify students' achievement in English language through explore the mean differences between control and experimental groups.

2. Identify students' motivation toward learning English language by exploring the mean differences between control and experimental groups.

\section{Importance of the Study}

The significance of the study comes from dealing with a new innovation (DST). It is known that most children across the world like social media like YouTube. They spent many hours in watching cartoon videos; DST strategy presents the content of subject matter taught in motivated way as similar as to YouTube way. DST strategy also simplifies the abstraction in English language themes and terms. Therefore, interestingly, 
this correlation is related to the implementation of the DST in the learning process as the study aimed to investigate. In fact, the study explicates that DST becomes a beneficial way for both of students and teachers. Finally, by incorporating this strategy, exhausting a direct and indirect way, this study tries to improve students' English and technological skills in learning English language. Besides, those skills, in the end, help a new generation to be up-to-date with a new innovative technology.

\section{METHOD}

\section{Research Design}

The researcher follows quasi experimental approach. Descriptive statistic and One-Way-ANACOVA were used to analysis data.

\section{Sample of the Study}

The sample of the study consisted of (50) male students from sixth grade were purposefully selected from Jerash public schools in the first semester at academic year 2017-2018. They were equally distributed into two groups: The first group is control group consisted of (25) students. They are taught English language by traditional way. On the other side, the second group is experimental group consisted of (25) students. They are taught English language by DST strategy.

\section{Instruments}

The current study has three instruments they are;

1. Achievement test: (25) multiple-choice questions were prepared by researcher based on the content analysis of the unit five (entitled "we are going to the bird park") which is included in English language textbook of sixth grade, after that the behavioral objectives of unit were identified according to the content analysis. Finally, table of specification was prepared which is included the outcomes of the unit five.

Achievement test validity and reliability: the test validate by ten of faculty members from Jordanian universities in the field of curriculum and instruction, measurement and evaluation, and methods of teaching English to ensure the linguistic integrity of the test's items, and its relevance to the students' levels. The experts modify, delete, and add some items, and the researcher takes the comments into consideration. The reliability of test was checked by conducting the test (pre-test) on (20) students from population of study. After two weeks, the researcher conducted the test (post-test) again on the same sample. The reliability value was (.87) which means the test has a high degree of reliability.

2. Motivation toward English Language Scale: Student' motivation towards English language learning scale with (20) items was developed based on the previous studies (Kasami, 2017; Glynn, Taasoobshirazi, \& Brickman, 2007, Tosun, 2013). The validity of questionnaire was checked by all (14) educational sciences faculty members at Jerash University. While the reliability was checked by using the questionnaire on (20) students from population of study. After two weeks, the researcher distributed the questionnaire again on the same sample. The reliability value was (.91) which means the questionnaire has a high degree of reliability.

3. Digital Storytelling: The DST was designed based on (ADDIE) model consist of five stages:

a. Analysis: In this stage, the researcher analysis students' needs and preferences, so that DST was designed in a convenient way that is relevant to the students' real life. Moreover, students' performances, abilities and motivations were analyzed.

b. Design: In this stage, the researcher set the desired behavioral objectives and outcomes such as students should be able to understand the main idea of lesson after watching DST; they should be able to recognize the new vocabularies and themes which are included in the story; and they should be able to express their opinions toward the story's events. 
c. Development: This stage includes gathering multimedia elements like; text, pictures, sounds and videos. The researcher collected the relevant multimedia throughout internet, recording sound, and scanning some picture from the unit five (we are going to the bird park). The researcher used Adobe Flash Cs5 and Sound Forge in order to produce the DST.

d. Implementation: In this stage, the DST was introduced to experimental group. The duration of current DST is eighteen minutes. DST material consists of all Unit five subjects, while the control group was taught the fifth unit (we are going to the bird park) by traditional way. The pre-test and post-test was conducted in the first semester of academic year 2017-2018.
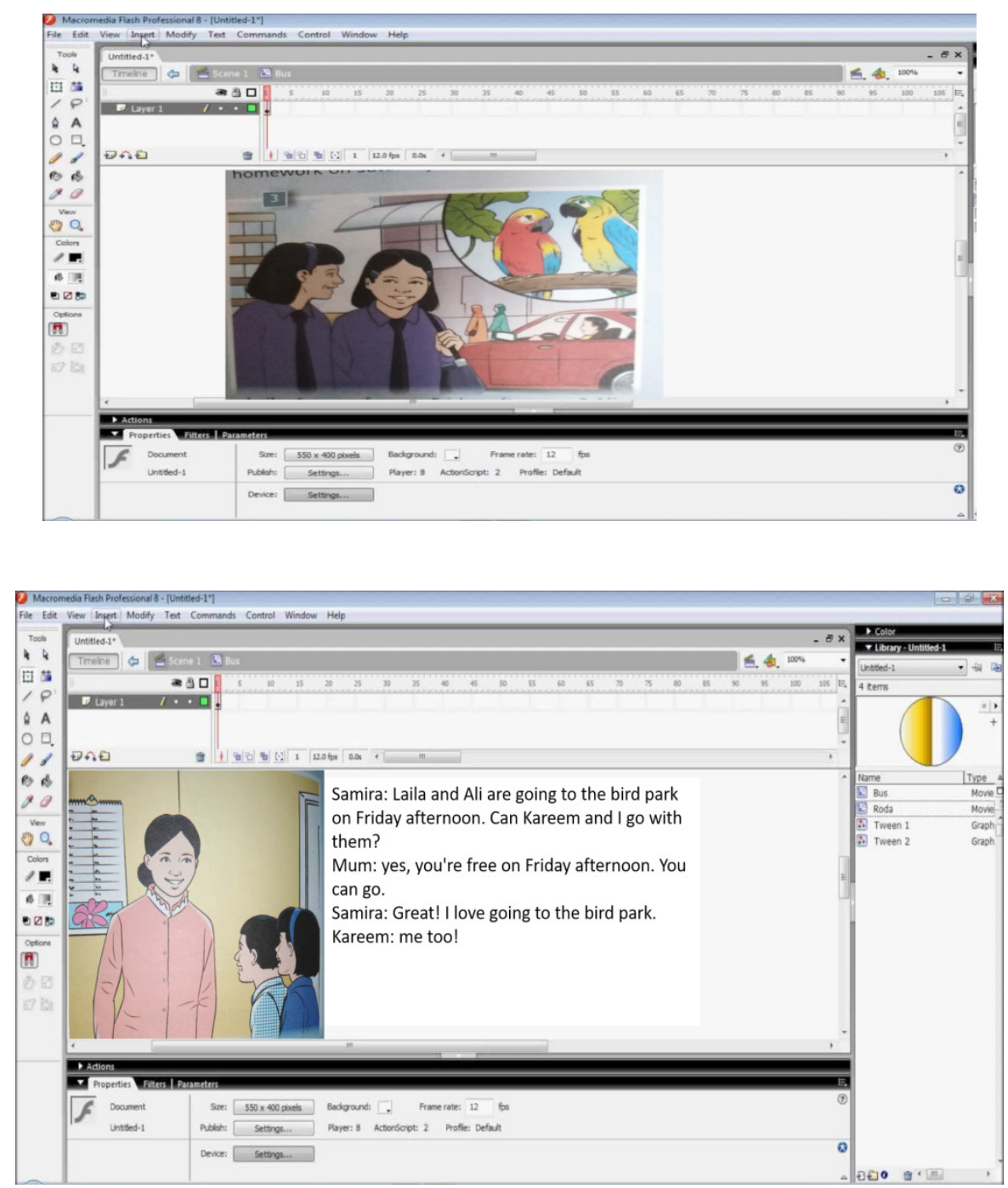

Figure 1. Digital storytelling application

e. Evaluation: In this stage, the researcher can determine the impact of the DST on students' achievement and their motivation toward learning English. Also the researcher conducts the evaluation throughout the achievement test and students' motivation scale.

The external validity of DST was validated by groups of educational technology professors from various Jordanian universities. All their comments were taken in to researcher's consideration. The researcher conducted DST on (20) students from population of study but out of the study's sample in order to check the usability and the ease of use of DST by students. Moreover, the purpose of pilot study is that find the ambiguous themes which may be faced by students. 


\section{RESULTS AND DISCUSSIONS}

\section{Result Related to the First Question}

"Are there significant differences in students' academic achievement due to teaching method (traditional way- DST)"?

To answer this question of the study means and standard deviations of students' academic achievement based on teaching method (traditional way- DST), were computed as presented in tables 1.

Table 1. Descriptive analysis of students' academic achievement scores due to teaching method (traditional way- DST)

\begin{tabular}{|c|c|c|c|}
\hline Group & Mean & Std. Deviation & $\mathrm{N}$ \\
\hline DST & 14.36 & 3.43 & 25 \\
\hline Traditional way & 10.68 & 3.66 & 25 \\
\hline Total & 12.52 & 3.97 & 50 \\
\hline
\end{tabular}

Table 1 shows that the mean scores of academic achievement of students in experimental group $(M=14.36$, $S D=3.43)$ were higher than students' scores in traditional group $(M=10.68, S D=3.66)$, to find out whether there are statistical significant differences in these means. One way ANCOVA was conducted and the results are shown in tables 2 .

Table 2. One way ANCOVA results of students' academic achievement based on teaching method (traditional way \& DST)

\begin{tabular}{lcccccc}
\hline \multicolumn{1}{c}{ Source } & $\begin{array}{c}\text { Type III Sum of } \\
\text { Squares }\end{array}$ & Df & Mean Square & F & Sig. & $\begin{array}{c}\text { Partial Eta } \\
\text { Squared }\end{array}$ \\
\hline PRE ach & 4.248 & 1 & 4.248 & .333 & .566 & .007 \\
Method & 169.602 & 1 & 169.602 & 13.309 & .001 & .221 \\
Error & 598.952 & 47 & 12.744 & & & \\
Corrected Total & 772.480 & 49 & & & & \\
\hline
\end{tabular}

Table 2 shows that there are statistically significant differences in students' academic achievement between two groups in favor of DST F $(1,47)=169.602, \mathrm{p}=.001$, partial eta squared $=.221$. This result may refer to a new strategy (DST) was designed in interesting way to attract students' attentions, also the nature of students (sixth grade) at this age prefer playing games and watching stories and learning. Thus, what is interesting in this data is that DST reinforces all of that features, in addition it contributes in grasping students' concentration, engaging students in given tasks and understanding ambiguous and abstract themes. All of these distinctive advantages of DST significantly had improved the students' achievement in the experimental group who had been taught English language by using DST strategy. In accordance with the present results, previous studies have demonstrated that Yang Wu (2012) study, in which all have indicated that using DST in learning English language could enhance students' performance. Finally, the result of the current study is in consistency with Kotluk \& Kocakaya (2017) study. It also has a positive correlation with Tahriri, Tous \& Movahedfar (2015) study. We can explain the results of current study that the students learn English language any time and any place by using DST; because of the teachers distributed DST CD into students. In this case, we notice that this strategy fill the gap between theory and practice. Those finding consisting with Atkas and Yurt (2017) study which is indicated DST had significant impact on academic achievement of students in Turkish literature course. 


\section{Result Related to the Second Question}

"Are there significant differences in students' motivation toward learning English language due to teaching method (traditional way- DST)"?

To answer this question of the study; means and standard deviations of students' motivation towards learning English language based on teaching method (traditional way / DST), were computed as presented in table 3.

Table 3. Descriptive analysis of students' motivation towards learning English language based on teaching method (traditional way- DST)

\begin{tabular}{|c|c|c|c|}
\hline Group & Mean & Std. Deviation & $\mathrm{N}$ \\
\hline DST & 4.19 & .403 & 25 \\
\hline traditional way & 3.09 & .473 & 25 \\
\hline Total & 3.64 & .706 & 50 \\
\hline
\end{tabular}

Table 3 shows that the mean scores of students' motivation in experimental group $(M=4.19, S D=.403)$ were higher than students' motivation scores in traditional group $(\mathrm{M}=3.09, \mathrm{SD}=.473)$, to find out whether there are statistical significant differences in these means. One way ANCOVA was conducted and the results are shown in tables 4 .

Table 4. One way ANCOVA results of students' motivation toward learning English language due to teaching method (traditional way / DST)

\begin{tabular}{ccccccc}
\hline Source & $\begin{array}{c}\text { Type III Sum of } \\
\text { Squares }\end{array}$ & Df & Mean Square & F & Sig. & $\begin{array}{c}\text { Partial Eta } \\
\text { Squared }\end{array}$ \\
\hline pre attitudes & .309 & 1 & .309 & 1.623 & .209 & .033 \\
GROUP & 14.893 & 1 & 14.893 & 78.199 & .000 & .625 \\
Error & 8.951 & 47 & .190 & & & \\
Corrected Total & 24.440 & 49 & & & & \\
\hline
\end{tabular}

Table 4 shows that there are statistically significant differences in students' motivation toward learning English language between two groups in favor of DST F $(1,47)=78.199, \mathrm{p}=.000$, partial eta squared $=$ .625. This result it may refer to that DST strategy enhances the interaction between students and teachers and between students themselves. It also supports the communication skills of the students. This can be explained that DST strategy gives the students the opportunities to express their opinions and summarize the story using their own language. There was a significant positive correlation between using the DST method and the students' progress. Therefore, this kind of learning motivate the experimental group students to learn English in motivated way in comparison with control group students who had been taught English language in conventional way, traditional way, or face-to-face teaching method. Data from this table can be compared with the data in previous literature (Bredvick, 2016; Kasami, 2017; Shernoff et al., 2003) which revealed that integrating DST in the learning and teaching process give students a high motivation to learn English language. Finally, the findings observed in this study mirror those of the previous studies that have examined the students' motivation towards the DST. This is may refer to that students around the world prefer to learn by fun such as video and DST. This is clear in previous studies (Connie, 2017; Ivala et al., 2013) which revealed that motivation is key and crucial factor in learning English language. 


\section{CONCLUSION}

One of the most significant findings to emerge from this study is that DST strategy is commonly used in modern schools. it also showed that DST simulates and imitates students' learning styles. In Fact, DST is an ideal way for presenting new, ambiguous, and abstract content.Thus, it is recommended as a meaningful tool to teach English language for foreign students especially in primary stage. These results explained up important insights into the significant role of DST in enhancing Students' ability in learning English.

In fact, DST blended multimedia together in order to produce useful story for the students, its duration is eighteen minutes approximately. Learning based on multimedia attract more senses compare with traditional learning, learning content through multimedia (DST) helps students to preserve and remember information easily. In other words, presenting the content as story is an interesting and enjoying technique which makes students more active, motivated and attractive to learn English language. As in our study, the more surprising correlation is flowing up with the DST positive impact on students' academic achievement in English language. Moreover, the most striking result to emerge from the data is that DST has a significant effect on the boosting students' motivation towards learning English language. Finally, the study has gone some way towards enhancing our understanding to the importance implementation of DST in the entire educational system of our schools or at least partially substantiates the traditional way in teaching.

\section{RECOMMENDATIONS}

Set of recommendations were presented according to the results of the study;

1. Integrating DST strategy in teaching and learning English language for the sixth grade.

2. Although the current study is based on a small sample of participants, the findings suggest holding intensive training courses in designing and using DST in classroom setting.

3. Conducting more studies about the impact of DST on students' achievement in other courses such as mathematics and science.

\section{BIODATA and CONTACT ADDRESSES of AUTHOR}

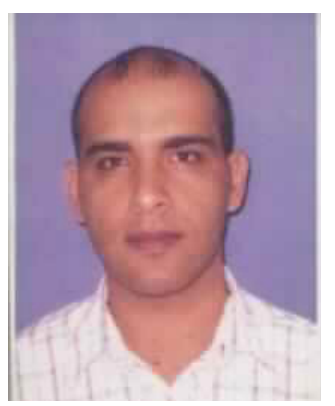

Dr. Yousef ALJARAIDEH, is an Associate Professor in Information and Communication Technology (ICT) in Education at Educational Sciences faculty, Jerash University. Dr. Aljaraideh gained his Ph.D. in Educational Technology at October, 2009 from University Utara Malaysia. His academic interest areas are learning ICT in Education, social network analysis, educational hypermedia and multimedia, Mobile Learning, open and distance learning, e-learning, and use of internet in education. Dr. Aljaraideh is a Director of Consulting Center at Jerash University, and $\mathrm{He}$ has over than 22 journal articles published in international indexes, and other national and international articles, 6 papers presented in international conferences

Dr. Yousef ALJARAIDEH

Department of Curriculum and Instruction, Faculty of Educational sciences

Address: Jerash University, 26150, Jerash, Jordan

Phone: 0096226350521

E-mail: yacob_yacob@yahoo.com 


\section{REFERENCES}

Abdel-Hack, E., \& Helwa, H. (2014). Using digital storytelling \& weblogs instruction to enhance EFL narrative writing \& critical thinking skills among EFL majors at faculty of education. Educational Research, 5(1), 8-41.

Abdolmanafi-Rokni, J., \& Qarajeh, M. (2014). Digital storytelling in EFL classrooms: The effect on the oral performance. International Journal of Language and Linguistics, 2 (4), 252-257. https://doi. org/10.11648/j.ijll.20140204.12

Alhmadi, N. (2014). English speaking learning barriers in Saudi Arabia: A Case Study of Tibah University. Arab World English Journal, 5( 2), 38-53.

Atkas, E., \& Yurt, S.(2017). Effects of digital story on academic achievement, learning motivation and retention among university students. International Journal of Higher Education, 6(1), 180-196. https://doi.org/10.5430/ijhe.v6n1p180

Bredvick, R. (2016). The effects of digital storytelling on student motivation and student engagement. Graduate Research Papers. 89. https://scholarworks.uni.edu/grp/89.

Benmayor, R. (2008). Digital storytelling as a signature pedagogy for the new humanities. Arts and Humanities in Higher Education, 7(2), 188- 204. https://doi.org/10.1177/1474022208088648

Chao, Y.W. \& Hung, H.T. (2014). An Exploratory Study on University Students' Perceptions of Using Digital Storytelling to Enhance English Learning. In T. Bastiaens (Ed.), Proceedings of World Conference on E-Learning (pp. 350-355). New Orleans, LA, USA: Association for the Advancement of Computing in Education (AACE).

Connie, S. (2017). Teachers' and students' perceptions of storytelling as a language teaching and learning resource. $\mathrm{PhD}$ Thesis, University of Sheffield, England.

Dreyer LM 2017. Digital storytelling to engage postgraduates in reflective practice in an emerging economy [Special issue]. South African Journal of Education, 37(4). https://doi.org/10.15700/saje. v37n4a1475

Dupain, M. \& Maguire, L. (2005). Digital storybook projects 101: How to create and implement digital storytelling into your curriculum. 21st Annual Conference on Distance Teaching and Learning.

Foelske, M. (2014). Digital storytelling : the impact on student engagement, motivation and academic learning. Master Thesis, University of Northern Iowa, USA.

Gakhar, S. (2007). The influence of digital storytelling experience on pre-service teacher education students' attitudes and intentions. Masters thesis, Iowa State University, USA.

Gay, G. (2010). Culturally responsive teaching: Theory, research and practice (2nd ed.). New York, NY: Teachers College Press.

Ivala, E., Gachago, D., Condy, J., \& Chigona, A. (2013). Enhancing student engagement with their studies: a digital storytelling approach. Creative Education, 4(10), 82. https://doi.org/10.4236/ ce.2013.410A012

Glynn, S. M., Taasoobshirazi, G., \& Brickman, P. (2009). Science motivation questionnaire: Construct validation with nonscience majors. Journal of Research in Science Teaching, 46(2), 127-146. https:// doi.org/10.1002/tea.20267

Kasami, N. (2017). The comparison of the impact of storytelling and digital storytelling assignments on students' motivations for learning. In K. Borthwick, L. Bradley \& S. Thouësny (Eds), CALL in a climate of change: adapting to turbulent global conditions - short papers from EUROCALL 2017 (pp. 177 183). Research-publishing.net. https://doi.org/10.14705/rpnet.2017.eurocall2017.709

Khan, T \& Khan, N. (2016). Obstacles in learning English as a second language among intermediate students of districts Mianwali and Bhakkar, Pakistan. Open Journal of Social Sciences, 4, 154-162. https://doi.org/10.4236/jss.2016.42021 
Kotluk, N. \& Kocakaya, S. (2017). The effect of creating digital storytelling on secondary school students' academic achievement, self efficacy perceptions and attitudes toward physics. International Journal of Research in Education and Science (IJRES), 3(1), 218-227.

LoBello, C. (2015). The impact of digital storytelling on fourth grade students' motivation to write. (Unpublished master's thesis). State University of New York, the USA.

Malita, L., \& Martin, C. (2010). Digital storytelling as web passport to success in the 21st century. ProcediaSocial and Behavioral Sciences, 2(2), 3060-3064. https://doi.org/10.1016/j.sbspro.2010.03.465

Meadows, D. (2003). Digital storytelling: Research-based practice in new media. Visual Communication, (2), 189-193. https://doi.org/10.1177/1470357203002002004

Mokhtar, N. H., Halim, M. F. A., \& Kamarulzaman, S. Z. S. (2011). The effectiveness of storytelling in enhancing communicative skills. Procedia Social and Bevioral Sciences, 18, 163-169. https://doi. org/10.1016/j.sbspro.2011.05.024

Nam, C. W. (2017). The effects of digital storytelling on student achievement, social presence, and attitude in online collaborative learning environments. Interactive Learning Environments, 25(3), 412-427. https://doi.org/10.1080/10494820.2015.1135173

Nilson, L. B. (2010). Teaching at its best: A research-based resource for college instructors. San Francisco, CA: John Wiley and Sons.

Ormrod, J.E. (2014). Educational psychology: Developing learning. 8th ed. Upper Saddle River, NJ: Pearson Education.

Robin, B. (2008). Digital storytelling: A powerful technology tool for the 21st century classroom. Theory Into Practice, 47, 220-228. https://doi.org/10.1080/00405840802153916

Robin, B. (2016). The power of digital storytelling to support teaching and learning. Digital Education Review, (30), 17-29.

Sarıca, H.C., \& Usluel, Y. K. (2016). The effect of digital storytelling on visual memory and writing skills. Computers \& Education, 94, 298e309. https://doi.org/10.1016/j.compedu.2015.11.016

Shernoff, D.J., Csikszentmiahlyi, M., Schneider, B. \& Shernoff, E.S. (2003). Student engagement in high school classrooms from the perspective of flow theory. School Psychology Quarterly 18, 207-231. https://doi.org/10.1521/scpq.18.2.158.21860

Smeda, N., Dakich, E., \& Sharda, N. (2014). The effectiveness of digital storytelling in the classrooms: A comprehensive study. Smart Learning Environments, 1(1), 1-21. https://doi.org/10.1186/s40561014-0006-3

Somdee M, Suppasetseree, S. (2012). Developing English Speaking Skills of Thai Undergraduate Students by digital storytelling through Websites. (Available at www.fllt2013.org/private_folder/ Proceeding/166.pdf).

Sylvester, R. \& Greenidge, W. (2009). Digital storytelling: Extending the potential for struggling writers. The reading teacher, 63(4), 284-295. https://doi.org/10.1598/RT.63.4.3

Tahriri, A., Tous, M. D., \& Movahedfar, S. (2015). The Impact of digital storytelling on EFL learners' oracy skills and motivation. International Journal of Applied Linguistics and English Literature, 4(3), 144153.

Tosun, C. (2013). Adaptation of Chemistry Motivation Questionnaire-II to Turkish: A Validity and Reliability Study. Journal of Education Faculty, 15(1), 173-202.

Wilson, J. A. (1997). A program to develop the listening and speaking skills of children in a first grade classroom. Retrieved December 2016, from http://files.eric.ed.gov/ fulltext/ED415566.pdf

Yang, Y., Wu, W. (2012). Digital storytelling for enhancing student academic achievement, critical thinking, and learning motivation: A year-long experimental study. Computer \& Education, 59, 339-352. https://doi.org/10.1016/j.compedu.2011.12.012 